International Journal of Innovative Studies in Aquatic Biology and Fisheries

Volume 5, Issue 4, 2019, PP 8-11

ISSN 2454-7662 (Print) \& ISSN 2454-7670 (Online)

DOI: http://dx.doi.org/10.20431/2454-7670.0504002

www.arcjournals.org

\title{
Culture Technology of Chinese Sucker (Myxocyprinusasiaticus)
}

\author{
Xiao-jiang Chen* \\ Jiangsu Agri-animal Husbandry Vocational College
}

*Corresponding Author: Xiao-jiang Chen, Jiangsu Agri-animal Husbandry Vocational College.

\begin{abstract}
The Myxocyprinusasiaticus is a rare and precious fish in the Yangtze River in China. It is listed as the second-class endangered rare animal in China. In order to reasonably develop the resources of Chinese Myxocyprinusasiaticus and explore the ways of artificial cultivation, which are conducive to the protection of resources and sustainable development, this paper mainly introduces the conditions of ponds, cultivation mode, feeding management, disease prevention and control, and puts forward the selection of appropriate models, the development of appropriate formula feed, the optimization of pond design, and the control of water quality to ensure artificial cultivation.
\end{abstract}

Keywords: Chinese Myxocyprinusasiaticus; Cultivation; Technology

\section{INTRODUCTION}

Chinese Myxocyprinusasiaticus is one of the most important economic fish in the upper reaches of the Yangtze River in China. It has not only edible value, but also great ornamental value. From March to April each year, the Myxocyprinusasiaticus lay eggs and propagate under the rapids of Jinsha River, Zhijiang and Jialing River. Juveniles go downstream along the Yangtze River, part into streams, part into lakes, and their maximum body weight is about $35 \mathrm{~kg}$. Because of the environmental damage caused by water conservancy projects and so on, the Myxocyprinusasiaticus cannot propagate in the upper reaches, resulting in a significant reduction in resources. Therefore, it is listed as the second-class protected animal in China [1-2]. Therefore, the market gap of artificial cultivation of Myxocyprinusasiaticus is large, and the cultivation of fry and adult fish culture technology need to be further improved.

\section{MATERIALS AND METHODS}

\subsection{Pond Conditions}

The pond area used for fry culture is 1500-3000 square meters, which is easy to manage. The pond is orientated from east to west, which can prolong the illumination time. The bottom of the pond is loam or gravel. The height of the pond is 2 meters and the highest water level is 1.6-1.8 meters. It is convenient to drain and irrigate. At the bottom, a micro-porous aeration pipeline was laid, about $20 \mathrm{~cm}$ away from the bottom[3]. Around the pond, about a tenth of the pond area is reserved for the construction of cement ponds, and aeration pipes are laid at the bottom of the cement pool. In the cement pool, the substrates are made of materials like volcanic rocks, coal cinder and ceramsite, and aquatic economic crops are planted to simulate artificial wetlands. Pump the water from the bottom of the culture pond to the treatment pond, and the microorganisms attach to the substrate to decompose organic matter, and then absorb excessive nutrients through aquatic cash crops to achieve the purpose of purifying the water, and then the treated water flows into the pond, so it has a complete water intake and outflow system.

\subsection{Water Quality Conditions}

The water source for aquaculture is Yangtze River water, and the water source is abundant. The $\mathrm{pH}$ is 7.28.5 and the dissolved oxygen is more than $6 \mathrm{mg} / \mathrm{L}$. At each pond, there is an independent storage and drainage system to prevent the spread of disease. The evaluation criteria adopted for water environment investigation in crab ecological aquaculture area are Class III criteria of Fishery Water Quality Standard (GB 11607-89)[4] and Surface Water Environment Quality Standard (GB 3838-2002)[5], and the pH 
is6.5-8.5, dissolved oxygen $\geq 5$. The requirement is that the water source is adequate and easy to draw and drain.

\subsection{Fingerling Stocking}

12 to 15 days before stocking, dry the pond and disinfect it, and the bottom silt was controlled to be about $20-30 \mathrm{~cm}$. Sprinkle $0.15-0.22 \mathrm{~kg}$ of quicklime evenly per square meter, and then expose for 5 days to kill pathogens. After water filling, along the edge of the pool, transplant 1.5 to 2.0 meters of aquatic grasses, such as water peanuts, for Chinese Myxocyprinusasiaticus to escape, prey, inhabit shelter and regulate water quality.

Choose Myxocyprinusasiaticus species with strong physique, bright body color, free movement and more sensitive response to external stimuli. The size of fish species is uniform, about 10 centimeters, and 2,000 fish are kept every 666 square meters. Before the fish are putinto the pond, we need to soak them in $3 \%$ salt water for 5 to 10 minutes. Each 666 square meter is matched with 160-200 silver carp of 200 grams, and 40-50variegated carp.

\subsection{Water Quality Management}

Because the aquaculture water body of Myxocyprinusasiaticus is small and its stocking density is high, there are many residual baits and excreta of Myxocyprinusasiaticus, which can easily pollute the water quality, affect the growth of Myxocyprinusasiaticus or induce fish diseases. Therefore, we need to constantly adjust water quality and water level. In the initial stage, we control the water level from 0.4 to $0.5 \mathrm{~m}$, and then gradually add water [6]. In April-May, the water level remains at 0.6-0.8 M. In the high temperature season, we should control the water level of 1.3-1.5 meters and remember to add fresh water. And we need to turn on the aerator regularly, keeping the water transparency between 25 and 30 centimeters. Water temperature, dissolved oxygen, nitrite, hydrogen sulfide, ammonia nitrogen and $\mathrm{pH}$ are measured regularly. Regularly use substrate improvers, such as calcium peroxide, zeolite, etc. Every half month to one month, light, biological active agents such as bacteria, EM bacterial solution and compound bacillus are put into the water to regulate the water quality and maintain the benign circulation of the water body. During the whole breeding period, the pond $\mathrm{pH}$ is between 7-8.5, NH3-N $<0.02 \mathrm{mg} / \mathrm{L}$, $\mathrm{NO} 2--\mathrm{N}<0.1 \mathrm{mg} / \mathrm{L}$, sulfide $<0.2 \mathrm{mg} / \mathrm{L}$ and dissolved oxygen is more than $5 \mathrm{mg} / \mathrm{L}$. As for water quality inspection, please refer to the Water and Wastewater Monitoring and Analysis Method (Fourth Edition).

\subsection{Bait Feeding and Routine Management}

Myxocyprinusasiaticus have small mouth diameter and high requirement for protein content in food. We choose the formula feed with diameter of $2 \mathrm{~mm}$ and protein content of more than 38\% [7], and add water, earthworm pulp, fish surimi and mussel surimi as food attractants. We should pay attention to the freshness of the food, avoid putrefaction and deterioration of the food. Fix the time and place of feeding, control the feeding amount according to the 4 to $8 \%$ of the bodyweight, and make corresponding adjustments according to season, weather and the intake and activity of Chinese Myxocyprinusasiaticus. Check the eating table; if there is a small amount of residual bait on it, it is OK. Ensure that the Chinese Myxocyprinusasiaticus is well fed. Feeding time is from 9 a.m. to 10 a.m. and from 16 to 17 p.m. Choose the appropriate size of bait according to different growth stages [8].

We should insist on the inspection of ponds in the morning and evening to observe the growth, feeding, activity of Myxocyprinusasiaticus and the changes of water quality. Check the water inlet and outlet to prevent fish from escaping and enemy invasion. Find out the abnormal situation, find out the reason in time and take corresponding measures to solve it in time and make good production records.

\subsection{Disease Control}

In order to effectively prevent fish diseases, we should adopt the principles of prevention as the main, prevention and treatment should be combined and prevention is more important than treatment[9].Specific practices are as follows: selection of high-quality fish species with strong physique and regular specifications; feed fresh, comprehensive-nutrition baits in line with the dietary habits of Myxocyprinusasiaticus; stocking density should be scientific and reasonable, and easy to manage; 
strengthen the water quality management, careful management and prevention of fish damage, and adhere to the ecological prevention and control. Before and after stocking, medicated baths and disinfection are carried out with drugs such apotassium permanganate or salt. In the growing season, every 15 days or so, quicklime should be applied once, and $75-150 \mathrm{~kg} / \mathrm{hm} 2$ each time. It can not only disinfectand prevent diseases, but also improve water quality, adjust $\mathrm{pH}$ value and increase calcium ion content. Real-time addition of micro-ecological agents can regulate water quality. In the process of aquaculture, the water body and feeding table need to be disinfected regularly. Appropriate cultivation, scientific feeding, drug prophylaxis and comprehensive measures should be taken to reduce the chance of disease infection and disease incidence.

\section{DISCUSSION}

\subsection{Intercropping Model}

The Myxocyprinusasiaticus, as an omnivorous fish species, mainly feed on benthic invertebrates, plant debris and organic matter in the mud. It has a nature of nature in the fry stage. It has a sweet temper and does not compete for food. It lives in the middle and lower layers of the water body. It has a strong habit of avoiding light, and does not have obvious or regular diurnal feeding or activity rhythm. It has the characteristics of congenital evolutionary corresponding to higher water velocity, and its strong swimming ability is related to its survival in torrents. Although Myxocyprinusasiaticus has strong swimming ability, its competitiveness in feeding commodity feed is not as good as carp, crucianor other species under the condition of artificial cultivation [10]. Wang Guiliang (2018). The polyculture mode of Myxocyprinusasiaticus, Pelteobagrusfulvidraco and Leiocassislongirostris has better benefits. He found that Myxocyprinusasiaticus are highly clustered, especially in the juvenile stage. Once they get sick, it will be highly infectious. The intercropping of peculiar fishes such as Pelteobagrusfulvidraco and Leiocassislongirostris in the main aquaculture pond of Myxocyprinusasiaticus can enrich the species of pond culture, avoid the risk of large number of deaths in the event of disease or in the event of irresistible natural disasters to a certain extent, and at the same time reduce the loss of farming benefits caused by fluctuations in market prices of a certain species, and improve the stability of the comprehensive benefits of pond culture. In this experiment, Myxocyprinusasiaticusis the main culture. At the same time, a small amount fish whose habitat and feeding habits are different from Myxocyprinusasiaticus, such as Hypophthalmichthys molitrix and Aristichthysnobilis, are put in the pond so as to make full use of the space resources of different aquatic layers and help to regulate water quality, improving the natural purification ability of fish ponds and achieving stable production and high yield. Considering the high protein content of Myxocyprinusasiaticus, we should choose a variety with similar diet and higher value forpolyculture.

\subsection{Large Size Myxocyprinusasiaticus Species Can Shorten the Cultivation Cycle}

Ma Jingang (2010) carried out intercropping of $15 \mathrm{~cm}$ Myxocyprinusasiaticus species in adult fish pond, and the density of the fish was $750-825 / \mathrm{hm} 2$. After 240 days of growth, the average survival rate was $89.05 \%$, the commodity rate was $100 \%$, and the average yield per unit area reached $697.5 \mathrm{~kg} / \mathrm{hm} 2$. The average survival rate of intercropping of 3.3-5cmMyxocyprinusasiaticus was $79 \%$ and the commodity rate was 89\%[11]. In the experiment of Chen Xiaojiang (2013), the size of Myxocyprinusasiaticus was $10 \mathrm{~cm}$. The average survival rate was $91.2 \%$ and the commodity rate was $100 \%$ after 250 days of cultivation. The fish density of pond 2 and pond 3 were $750 / \mathrm{hm} 2$ and 900/hm 2 respectively. The yield of Myxocyprinusasiaticus was $342 \mathrm{~kg} / \mathrm{hm} 2$ and $405.75 \mathrm{~kg} / \mathrm{hm} 2$ respectively [12]. Species size was one of the main influencing factors.

\subsection{Build a Good Ecological Environment to Prevent Diseases}

During the whole experiment period, no large-scale disease should be found, the prevention works mainly relied on is done well and a good aquaculture ecological environment is created. Before releasing fry, we should thoroughly disinfect ponds; formulate reasonable stocking density; regularly apply microecological agents to regulate water; regularly open microporous aerator to maintain sufficient dissolved oxygen in water; manage and control the growth of aquatic plants; add vitamin $\mathrm{C}$, immune 
polysaccharides to bait during the disease-susceptible season (June-October) to prevent the occurrence of disease by enhancing autoimmunity.

\section{CONCLUSION}

Artificial cultivation of Chinese Myxocyprinusasiaticus and selection of appropriate mode can improve the efficiency of cultivation and reduce the risk of cultivation. Choosing suitable formula feed can reduce the cost, shorten the breeding cycle and improve the quality of commodities. Optimizing pond design and doing well in water quality control can effectively prevent the occurrence of most diseases.

\section{ACKNOWLEDGMENT}

This research was financially supported by "Qing Lan Project of Jiangsu Province". This work was supported by"311 Talents Project in Taizhou" and Jiangsu Agri-animal Husbandry Vocational College (Grant No.NSFPT201739).

\section{REFERENCES}

[1] Zhang C, Zhao Y, Kang J. A discussion on resources status of Myxocyprinusasiaticus (Bleeker) and their conservation and the recovery. Journal of Natural Resources, 2000, 15:155-159.

[2] LeheL, Guoxi W, Zhiling W. An effect of the gezhou dam key water control project on sexual gland development and natural spawning of Chinese sucker Myxocyprinusasiaticus in the downstream below the dam [J]. Journal of Fisheries of China, 1992.

[3] Zhou J, Yang D, Wu G, et al. Development of Chinese sucker (Myxocyprinusasiaticus) larval and juvenile and techniques for fry and fingerlings rearing. Journal of Huazhong Agricultural, 1999, 18:263-267.

[4] GB 11607-89, Water quality standard for fisheries[s]. China SEPA.

[5] GB 3838-2002, Environmental quality standards for surface water [s].China SEPA.

[6] Chen X J, Zhu Y G, Zhao Z M. The Influence of Micropore Oxygen Aeration on the Pond Water Quality Environment [J]. Advance Journal of Food Science \& Technology, 2013, 5(11):1478-1482.

[7] Chu Z J, Gong Y, Lin Y C, et al. Optimal dietary methionine requirement of juvenile Chinese sucker, Myxocyprinusasiaticus. Aquaculture Nutrition, 2014, 20(3):253-264.

[8] Song Z, Fu Z, He C, et al. Effects of temperature, starvation and photoperiod on otolith increments in larval Chinese sucker, Myxocyprinusasiaticus. Environmental Biology of Fishes, 2009, 84(2):159-171.

[9] Fang L B, Xiao-Hong L, Hai-Long G, et al. The discovery of, Clinostomumcomplanatum, metacercariae in farmed Chinese sucker, Myxocyprinusasiaticus [J]. Aquaculture, 2018, 495:273-280.

[10] Yuan Y C, Yang H J , Gong S Y, et al. Effects of feeding levels on growth performance, feed utilization, body composition and apparent digestibility coefficients of nutrients for juvenile Chinese sucker, Myxocyprinusasiaticus[J]. Aquaculture Research, 2010, 41(7):0-0.

[11] Ma J.G, He Y.K, Wan J.Y. Study on the technology of cochineal fish intercropping in fish ponds. Modern Agricultural Science and Technology, 2010 (8): 334-334.

[12] Chen X J, Wang J, Zhu Y Y, et al. Test of intercropping Myxocyprinusasiaticus in the Eriocheirsinensis pond [J]. Advance Journal of Food Science \& Technology, 2013, 5(10):1361-1366.

Citation: Xiao-jiang Chen, "Culture Technology of Chinese Sucker (Myxocyprinusasiaticus)". International Journal of Innovative Studies in Aquatic Biology and Fisheries, 5(4), pp.8-11.http://dx.doi.org/10.20431/24547670.0504002

Copyright: () 2019 Authors. This is an open-access article distributed under the terms of the Creative Commons Attribution License, which permits unrestricted use, distribution, and reproduction in any medium, provided the original author and source are credited. 